
internationales

vol. $21-n^{\circ} 3 \mid 2005$

Familles, destins personnels et appartenances

collectives en migration

\title{
The Chances of the second Generation in Families of migrant Entrepreneurs
}

Quality of Life Development as a biographical Process

\section{Ursula Apitzsch}

\section{(2) OpenEdition \\ Journals}

\section{Electronic version}

URL: https://journals.openedition.org/remi/2517

DOI: $10.4000 /$ remi. 2517

ISSN: $1777-5418$

\section{Publisher}

Université de Poitiers

\section{Printed version}

Date of publication: 1 December 2005

Number of pages: 83-94

ISBN: 2-911627-45-8

ISSN: 0765-0752

\section{Electronic reference}

Ursula Apitzsch, "The Chances of the second Generation in Families of migrant Entrepreneurs", Revue européenne des migrations internationales [Online], vol. 21 - n³ | 2005, Online since 01 December 2008, connection on 16 April 2022. URL: http://journals.openedition.org/remi/2517 ; DOI: https://doi.org/ 10.4000/remi.2517

This text was automatically generated on 16 April 2022.

(C) Université de Poitiers 


\title{
The Chances of the second Generation in Families of migrant Entrepreneurs
}

Quality of Life Development as a biographical Process

\author{
Ursula Apitzsch
}

1 The hypothesis presented in this paper ${ }^{1}$ is that, from a biographical perspective, those engaged in ethnic businesses ${ }^{2}$ will give their quality of life $^{3}$ a high evaluation despite hard working conditions. This is because the business project represents a biographical achievement of economic and social integration in society that counteracts the prevailing racist prejudice and xenophobic stereotypes. However, this positive evaluation is coupled with objectively poor working conditions, which strongly influence the life of the spouses and the younger generation. This is the case independently of the level of their engagement in the business work, which is frequently intensive. Work in ethnic businesses has been understood as extreme selfexploitation and exploitation of others: long working hours, intensive work pressure, marginal working shifts, lack of free time and breaks during work, as well as the exploitation of the labour of family members, are characteristics of work in ethnic businesses. Moreover, ethnic businesses are mostly located on the fringes of the national economic systems (Rath, 2000), in sectors with low entry barriers that are abandoned by indigenous entrepreneurs because of the intensive and inferior working conditions and low profit margins (Waldinger, 1990).

2 The relative well being of the parents might be accompanied by worsening opportunities for the younger generation to accumulate educational, social and cultural capital and towards integration in society.

3 A hypothesis further to be elaborated is that there are gender-specific processes related to different roles, work and care responsibilities and different kinds of ties to business and home. Because of these differences, female children of ethnic entrepreneurs might tend to strive for better educational qualifications and to have higher expectations for a vocational career in the labour market. Male children, even if 
they are also oriented towards a vocational career outside the family business, might develop less human capital through poor educational performance (cf. Delcroix, 2001).

\section{Motivations for migrant self employment}

4 The success of ethnic entrepreneurship has been explained by their personal willingness to work hard in order to achieve the economic goals of the migration project, but also by the ethnic solidarity that supplies entrepreneurs with necessary resources (Bonacich, 1973; Light/Karageorgis, 1994; Light/Gold, 2000). The capacity of ethnic entrepreneurs to rely on the labour of family members is regarded as a considerable part of the ethnic resources available (Light/Gold, 2000). According to others (Moallem, 1991; Min/Jaret, 1985), family resources provide compensation for the absence of resources of the privileged social classes entering entrepreneurship, which secure ethnic entrepreneurs' successful business projects (Light/Karageorgis, 1994; Light/Gold, 2000).

5 Some initial answers to the question of the quality of life of ethnic entrepreneurs are provided by the marginality of ethnic entrepreneurship, as well as the specific, ambivalent and stressful character of entrepreneurial activity in general. This implies being independent from orders given by others, but in turn, being extremely dependent on clients and market movements; being free to act, but forced to establish routines, being dependent on the visions that enable creativity, but also forced to act permanently, being free from the risk of losing the job, but permanently running the risk of failing as an entrepreneur (Johannisson/ Senneseth, 1993).

The importance of intrinsic motivation to entrepreneurship has been identified as a component that influences the self-perception of entrepreneurs and their sense of the quality of life (Newby et al., 1999). Recent biographical research (Apitzsch and Kontos, 2003) has stressed that the self-evaluation of migrants in relation to their entrepreneurial projects is complex, multi-layered, and in some respects positive. This "after all positive" self-evaluation is explained by the embeddedness of the entrepreneurial activity in a wide-ranging biographical process (Apitzsch, 2003; Kontos, 2004) deriving social recognition from the entrepreneurial activity and entrepreneurial success. Of great importance in this context is the sense of being able to earn one's own living in an economy that excludes migrants and condemns them to be passive receivers of welfare benefits, blaming them at the same time for being unwilling to work and live at the expense of the state (Kupferberg, 2003).

\section{Critique of precarious life conditions in ethnic family business}

7 Ethnic businesses are mostly family businesses, which means that the internal organisation of family units will be the main focus of the proposed project. The "new economics of migration" regards families or households as collective actors striving not only "to maximise expected income, but also to minimise risk and loosen constraints associated with a variety of market failures" (Massey et al., 1993: 436). Consequently some family members may work in the family business while others are occupied in the local market or work abroad. 
8 The relevance of family relations, as well as spouses and children's work in ethnic business has implicitly been conceptualised in research on ethnic business, especially in the framework of "ethnic" versus "class" resources. In this concept, the significance of ethnic resources, i.e. resources available through ethnic solidarity and ethnic social relationships, is emphasised as a way of understanding the entrepreneurial activity of members of ethnic minorities who are poorly supplied with class resources, i.e. economic capital, education, symbolic capital and access to influential economic and institutional networks (Light and Rosenstein, 1995; Light and Gold, 2000). The notion of social embeddedness of ethnic business refers to the ways in which networks of social relations and acquaintances generate the trust needed for entrepreneurial activity, and support and discourage breach of trust in economic transactions. Wider networks, however, are also related to ambivalence, support and burdens. The ambiguity entailed by social relationships has been stressed in recent research in terms of support for and constraints on entrepreneurship. Constraints are seen, for instance, in the form of exaggerated claims on the entrepreneur legitimised through ethnic solidarity and the principle of reciprocity (Portes and Sensenbrenner, 1993; Granovetter, 1995).

9 The family is seen as the unit in which trust and reciprocity develop in a more comprehensive sense. Thus, in research on (ethnic) entrepreneurship, there is a risk of regarding a kin or family group as a harmonious entity and implying that all its members share the fruits of success equally. A focus on group/collectivist strategies and group solidarity has led to gender bias and gender blindness, as well as generation bias and blindness in studies on ethnic entrepreneurship. These studies have been insensitive to the ways in which the gender and generational division of labour shape the outcomes of upward mobility for specific individual members of a group. The result has been blindness to gender and generational specificity in the functioning of the power structure in many ethnic communities. This approach overemphasizes ethnic group "solidarity" and also fails to see the costs of entrepreneurship: inequality and oppression of ethnic labour. This has been shown by research on the garment industry (Morokvasic, 1988; Morokvasic, 1991; Phizacklea, 1990; Waldinger, 1990).

10 Consequently, on a socio-political level, the assumption of low quality of life in ethnic business has produced a vehement critique of ethnic business as an inferior and precarious form of work (Rath, 2000; Phizacklea, 1988), as well as a critique of the sociopolitical discourse on self-employment in European countries which promotes selfemployment as a reasonable and valuable path to social inclusion (Meager/Bates, 1999). This critique has also stressed the previously raised issue of the integration of the labour of women (mothers, spouses) and the younger generation into the business work process as an exploitation of family labour (Anthias, 1992).

11 However, both ethnic business research and self-employment research have so far tended to neglect the issue of agency. In ethnic business research, agency figures as a collective achievement of actors firmly embedded in social relations. Agency is neglected in researching self-employment when it is mainly seen as a response to the threat of social exclusion and the focus is on policies and on outsourcing activities of big firms. The existing intrinsic motivation to entrepreneurship, mostly observed among small entrepreneurs (Carland et al., 1984), has scarcely been taken into account in the case of ethnic business. The failure to consider agency has wide-reaching implications and also makes ethnic business research gender blind. The key importance of gender in ethnic business has been shown by feminist research (Westwood/Bhachu, 1988; Morokvasic, 
1988, 1991). Taking into account the agency of ethnic entrepreneurs opens up a perspective on gender relations in ethnic business research. Furthermore, it does justice to the multi-layered nature of self-employment, e.g., by relating intrinsic motivation to self-evaluations.

Overcoming the split between objective and subjective factors, the proposed research works with a biographical approach that sheds new light on the processes of quality of life, such as identifying objective opportunities which have enabled or led to the realisation of biographical plans and choices. In this, we follow the approach developed in the framework of the "human development" discussion, focusing, among other things, on the capacity of the subjects to realise what they consider important for their well-being (Sen, 1993) as a central aspect of quality of life (ul Haq, 1995: 20; Sen, 1993). We understand individual "choices" as embedded in biographical processes in terms of biographical plans, action schemes and trajectories. This helps us to better understand the crucial issue of social policy: what people want and what people need (Veenhoven, 2001).

The dynamic concept of the biographical embeddedness of the quality of life is processoriented. It refers to intergenerational aspects, such as the intergenerational impact of the quality of life (Noll, 2000). The frequent involvement of family members of the ethnic entrepreneur in business work raises the question of quality of life not only for the other adult members of the family, the spouses and possibly the grandparents, but also for the younger generation.

\section{Considering migrant family business in an intergenerational perspective}

14 Families "are made up of men and women and generations with different - sometimes opposing - interests, needs and resources. Consequently, families are locations of conflict and negotiation among members with regard to the allocation of prestige, responsibility, assets, decision making, group identity and moral credibility" (Light/Gold, 2000: 132).

Feminist research has revealed the complexity of gender relations in ethnic businesses. Women who have experience in paid work, although subordinate, are less prone to be marginalised in family business. They have experienced empowerment, which is also transferred to the family firm, and have access to and control over the products of their labour (Westwood/Bhachu, 1988: 6).

As mentioned above, feminist analysis has criticized the assumption of harmony in theoretical work on ethnic business and stressed the gender blindness of this research (Anthias, 1992; Phizacklea, 1988). The position of children in ethnic business has been less explored than the position of women. An exception is the work of Miri Song (1999) who has studied negotiation activities between family members in the ethnic business family in the shape of the virtual "family work contract" which regulates mutual expectations and obligations in the case of Chinese takeaways in England.

17 Research has shown that with each succeeding generation conflicts within family businesses tend to increase, and that rates of self-employment decline (Goldscheider, 1980). Issues of contention between generations nearly double between the first and third generation (Fenn, 1995). Children may reject economic activities their parents 
select for them in ethnic ownership. Sometimes parents feel that self-employment is not a desirable path. They make efforts to keep their offspring away from the family occupation and instead encourage educational achievement as a path to other careers (Rubin, 1994).

It is obvious that work organisation in ethnic family business has a strong impact on the lives of the second generation. Children are frequently involved in the business (Song, 1999). Even when children of ethnic entrepreneurs are not involved with their labour in the business work, they are frequently deprived of a normal family life because of the exhausting working hours of both parents in the business (Apitzsch/ Kontos, 2003). Our question is how the specific work situation in ethnic business impacts on the life chances of the children, who may be involved or not in business work, and how resources and chances for the second generation are shaped under the living and working conditions in ethnic businesses. While parents may possibly be content with their life conditions in terms of a biographical achievement, at the same time their children might have poor educational chances and life prospects. Can resources which are available to the parents be transferred to their children, and under what conditions? Are resources that enable ethnic entrepreneurship an asset or rather an obstacle to resource accumulation for the second generation?

There are different forms of integration of men, women and children in ethnic business. These forms of integration will have to be taken into account in analysing the quality of life in ethnic business.

\section{Migrant women as a "resource" for ethnic entrepreneurs}

20 Migrant women are involved in the ethnic economy in various ways and degrees of formality. A woman can be a business partner and co-entrepreneur, she can be employed in the business of the husband, she can be declared as an assisting family member, or she can be involved in an informal and unregistered way. In terms of division of labour, she can be involved in entrepreneurial-managerial tasks, she can be in charge of the bookkeeping or of another skilled function in the production process of the enterprise, or she can be a marginal help. Wives are mostly fully integrated in the tasks of the business as assisting family members without formal payment or social insurance (Light/Gold, 2000). Most feminist researchers have stressed the issue of exploitation: "enclave employment is most exploitative for women" (Gilbertson, 1995).

\section{Migrant women as autonomous entrepreneurs}

21 However, migrant women can also be autonomously self-employed. In some rare cases the husband is the assisting family member, but mostly he is not involved in the business at all or the enterprising woman is not living in a partnership. The number of autonomously self-employed ethnic women has been growing rapidly in recent years. Many self-employed women previously worked in a family business. A transition from assisting family member to autonomous entrepreneur has been noted (Kontos, 2001).

US ethnic business research reveals that migrant women's entrepreneurship is mostly located in the informal sector, that it depends on community members as customers and is limited to a labour force of female co-ethnics (Moallem, 1991). European research has shown that ethnic women entrepreneurs, in contrast to ethnic male entrepreneurs, 
do not rely on ethnic resources by employing co-ethnics (Hillman, 1998). In the case of employment of co-ethnics, these are mainly women, since women can give orders only to other women (Phizacklea, 1988: 22). Ethnic women entrepreneurs also do not rely on family labour as men do (Anthias/Mehta, 2003). This would mean that they are unlikely to involve the labour of their children in their business work. Therefore, the question will be on which basis family relationships and care duties are shaped in the family of a female ethnic entrepreneur, and what impact these relationships have on the future of the children.

\section{Children who are integrated via their labour in ethnic business}

Only recently has children's labour in ethnic business been investigated. In the case of Chinese takeaways in England. M. Song (1999) has analysed the internal family relations between parents and children that emerge in the form of a virtual "family work contract". She draws attention to the ambivalent attitude of the children to their position in this context.

Neither the impact of the integration of children's labour in ethnic business nor that of the integration of the labour of both parents in the business on the future chances of the children has yet been explored, and this study aims to correct these omissions. Human capital is a major resource for economic and social integration in modern societies. The analysis relies on the assumption that accumulation of human capital in childhood is a product of the attention and time devoted by parents to the educational tasks of the children, understood as social capital in family relationships (Coleman, 1988).

\section{Children of ethnic entrepreneurs who are not integrated in the business}

There has so far been no investigation of the impact of the working conditions in ethnic business on the life chances of the children when these are not regularly integrated in the business work. The mechanisms and processes of accumulation of human, social and cultural capital have to be explored.

The educational and vocational orientation of the next generation has to be be investigated from a gender-specific perspective on the migration project of the parents that conditions the intergenerational and vocational orientation of the second migrant generation. We apply this finding from migration research as a hypothesis to ethnic business, in asking about the gender-specific evaluation of the business project of the parents and its impact on the vocational life plans of the children. The quality of life in ethnic business and the interdependence with processes of the transfer of human, social and cultural capital to the younger generation have to be shown.

Moreover, family members' and children's labour in ethnic business raises the issue of their (long-term) integration in the negotiation of business strategies. This concerns especially the question whether social capital, e.g., in terms of a clientele, can be kept by the younger generation when they go on to other businesses or professions - as earlier research among native French business owners and the younger generation in their families suggests (Bertaux and Bertaux-Wiame, 1981; 1988). With regard to 
immigrant families, a comparable accumulation of social capital over generations, such as keeping a clientele, could indicate aspects of longer-term processes of social integration. A related question for the planned research is whether attempts to leave ethnic niches and "break out" could be realised through the contribution of children, for instance through their capability to master technological innovation. The research will thus also show whether and how the younger generation contributes to the response of business to technological innovation, opening up new market or other opportunities in this way.

We have argued that this process is taking place in a field made up of the influences of family and business strategies, personal interests of the individual persons, cultural bonds, individualisation tendencies and socio-political influences, and that these factors influence the individual persons in a gender-specific manner (Auster et al., 1984). To compensate tendencies for being excluded, diasporic bonds (James, 1994) are activated in order to support the life chances of the younger generation. The life of the younger generation might in this sense be more globalised and transnationalised than that of the first generation (Anthias, 1998).

\section{Policy perspectives}

Research on educational performance in OECD countries (OECD 2001) has revealed that poor educational performance correlates with low social class, and that lower class children are mostly children of migrants. Our research on the quality of life processes is concerned with issues of education among the specific group of migrant children in families of ethnic entrepreneurs.

In consequence, the expected benefits for the scientific discussion are firstly an improvement in our understanding of the critical relationship between selfemployment in the form of ethnic business and quality of life, and secondly the development of a biographically and intergenerationally sensitive instrument, with which we can analyse the quality of life.

Our findings about the mechanisms governing the inheritance of inequality and the mechanisms of transfer of resources to the next generation will contribute to the formulation of policies for the support of families engaged in ethnic business. Factors will be identified that assist or hinder the young generation in the development of their own life plans and the accumulation of resources. These include both educational resources and motivational resources, such as life plans and the younger generation's own wishes.

Our research addresses two aspects of work in ethnic business that are related to the central aims of social policy as formulated in the European Social Agenda (2000-2005): the improvement of "quality of work" and the establishment of balanced ways of combining working life and personal life, as well as the well-being of the second generation. The issue of integration of the labour of children in ethnic business contradicts the prevailing notion of childhood in Europe. Children are thought of as being dependent and requiring economic resources, rather than active producers in the economic process. Research on parent-child exchange emphasises the transfer of care and welfare from parents to children (Cheal, 1983; Rossi/Rossi, 1990). Children's productive integration into economic activity is thought of as a custom from the past, or as a necessity caused by poverty in the Third World, whereas protective legislation 
and mandatory schooling limit children's labour (Anderson, 1980; Lewis, 1986). Childhood, as an idealised stage, is a normative expectation and a right for children in contemporary Europe (Aries, 1972).

Family business is a field of informal and unregulated work, that is hardly regulated through policy. Policies have been discussed, which would tend to formalise the work of assisting family members - in this case only spouses are included in this category in the family business. The work of children has been invisible for policy, and there is a policy vacuum in this field. Thus, our further research will shed light on a hidden side of ethnic business. On the basis of the findings, suggestions for supporting and regulating policies to improve the protection of families and children in ethnic business will be formulated. The goal of such policy suggestions will be to minimise the inheritance of inequality in ethnic business and at the same time to maintain the benefits of ethnic business, which makes social and economic integration a possibility for migrants threatened by exclusion.

\section{BIBLIOGRAPHY}

ANDERSON Michael (1980) Approaches to the History of the Western Family 1500-1914, London, Macmillan.

ANTHIAS Floya (1998) “Evaluating Diaspora: beyond ethnicity?”, in Sociology, Vol 32(3): 557-580.

ANTHIAS Floya (1992) Ethnicity, Class, Gender and Migration, Aldershot.

ANTHIAS Floya and MEHTA Nishi (2003) Gender, Migration and a Self-employment: Gender Divisions and Ethnic Enterprise. In Ursula Apitzsch and Maria Kontos, (ed): Self-employment, gender and Migration. In: International Review of Sociology Vol. 13, No.1, Monographic Part, London: Taylor \& Francis, pp. 105-117.

APITZSCH Ursula (2003) Inidividuelle Bearbeitung sozialer Unsicherheit in prekären Migrationsverläufen: Self employment als biographischer Prozess. In: Entstaatlichung und soziale Sicherheit. Verhandlungen des 31. Kongresses der Deutschen Gesellschaft für Soziologie in Leipzig 2002, Teil 1, Plenum II, herausgegeben von Jutta Allmendinger, Opladen: Leske+Budrich, S. 219 - 236.

APITZSCH Ursula (ed.) (1999) Migration und Traditionsbildung, Opladen and Wiesbaden: Westdeutscher Verlag.

APITZSCH Ursula and KONTOS Maria (ed) (2003) Self-employment, gender and Migration, In International Review of Sociology Vol. 13, No.1, Monographic Part, London: Taylor \& Francis, pp. 67-235.

ARIES Phillipe (1972) Centruries of Childhood, London Routledge.

AUSTER Ellen and ALDRICH Howard (1984) "Small Business Vulnerability, Ethnic Enclaves, and Ethnic Enterprise”, pp 39-54, in Ethnic Communities in Business, edited by Robin Ward, and Richard Jenkins. Cambridge: Cambridge University Press. 
BERTAUX Daniel (1990) Oral history approaches to an international social movement. Comparative Methodology: Theory and Practice in International Social Research. E. Oyen. London, Sage Publications: 151-171.

BERTAUX Daniel and Isabelle BERTAUX-WIAME (1988) "Le patrimoine et sa lignée: Transmissions et mobilité sociale sur cinq générations”, In Life Stories/Récits de vie, 4.

BERTAUX Daniel and Isabelle Bertaux-Wiame (1981) Artisanal Bakery in France: How it Lives and Why it Survives, In Bechhofer, Frank and Brian Elliott: The Petite Bourgeoisie. Comparative Studies of the Uneasy Stratum. London and Basingstoke, The Macmillan Press: 155-181.

BONACICH Edna (1973) A Theory of Middleman Minorities, In American Sociological Review, Vol. 38.

BONACICH Edna and MODELL John (1980) The Economic Basis of Ethnic Solidarity. Berkeley and Los Angeles: University of California Press.

CARLAND J.W., HOY F., BOULTON W.R. and CARLAND J.A.C. (1984) Differentiating entrepreneurs from small business owners: A conceptualization, In Academy of Management Review 9 (2), pp. 354-359.

CHEAL David (1983) Intergenerational family transfers. Journal of Marriage and the Family 45: 805-13.

COLEMAN James S. (1988) Social Capital in the Creation of Human Capital, In American Journal of Sociology 94, pp. 95-120.

DELCROIX Catherine (2001) Ombres et lumières de la famille Nour. Comment certains résistent face à la précarité, Paris, Payot.

EMIRBAYER Mustafa and GOODWIN Jeff (1994) Network Analysis, Culture, and the Problem of Agency, In American Journal of Sociology S. 1411-1454

FENN Donna (1995) Benchmark: Sources of Conflict in Family Business. http://www.inc.com/incmagazine/archives/07950962.html

GILBERTSON Greta, A. (1995) Women's Labor and Enclave Employment: The Case of Dominican Women in NYC, In International Migration review 29 (3).

GLATZER Wolfgang and ZAPF W. (eds.)(1984) Lebensqualität in der Bunderepublik. Objektive Lebensbedingungen und subjektives Wohlbefinden, Frankfurt/M. /New York.

GOLD Steven (1992) Refugee Communities: A comparative Field Study. Newbury Park CA: Sage. GOLDSCHEIDER Calvin and KOBRIN Frances E. (1980) Ethnic Continuity and the Process of SelfEmpoyment, In Ethnicity 7, pp. 256-278.

GRANOVETTER Mark (1985) Economic Action and Social Structure: The Problem of Embeddedness, In American Journal of Sociology, 91, pp. 481-510.

GRANOVETTER Mark (1995) The Economic Sociology of Firms and Entrepreneurs, In Portes Alejandro(Hg.) The Economic Sociology of Immigration. Essays on networks, Ethnicity, and Entrepreneurship, New York, Russel Sage Foundation S., pp. 128-165.

HILLMANN Felicitas (1998) Türkische Unternehmerinnen and Beschäftigte im berliner ethnischen Gewerbe, FS I 98 - 107, Discussion Paper, Wisenschaftszentrum Berlin, Berlin.

JAMES Clifford (1994) “Diasporas”, Cultural Anthropology 9(30), pp. 302-38.

JOHANNISSON Bengt, SENNESETH Knut (1993) Paradoxes of entrepreneurship, In Heinz Klandt (Ed.), Entrepreneurship and Business Development, Ashgate, Aldershot et al. 
KONTOS Maria (2004) Considerations on the biographical embeddedness of ethnic entrepreneurship, In Apitzsch, Ursula/ Bornat, Joanna and Prue Chamberlayne (eds.): Biographical Methods and Professional Practice. An international perspective, Bristol: The Policy Press, pp. 57-73.

KONTOS Maria (2001) Von der “mithelfenden Familienangehörigen” zur selbständigen Migrantin. Ein sozialer Transformationsprozeß in der Migration, In Büttner, Chr. und Meyer, Berthold (Hrsg.) Integration durch Partizipation. "Ausländische Mitbürger” in demokratischen Gesellschaften, Frankfurt/Main.

KREIDE Regina (2003) Self-employment of Women and Welfare-state Policies, In Ursula Apitzsch and Maria Kontos (eds): Self-employment, Gender and Migration. In: International Review of Sociology Vol. 13, No.1, Monographic Part, London: Taylor \& Francis, pp. 205-219.

KUPFERBERG Feiwel (2002) The Established and the Newcomers: What makes Immigrant and Women sntrepreneurs so special. In: Apitzsch, Ursula/Kontos, Maria (eds): Self-employment, Gender and Migration. In: International Review of Sociology Vol. 13, No.1, Monographic Part, London: Taylor \& Francis, pp. 89-105.

LEWIS Jane (1986) Anxieties about the family and the relationship between parents, children and the state in twentieth-century England. In Children of Social Worlds, ed. Martin Richards and Paul Light Cambridge Polity Press.

LIGHT Ivan and GOLD Steven (2000) Ethnic Economies, San Diego, Academic Press.

LIGHT Ivan and ROSENSTEIN Carolyn (1995) Expanding the Interaction Theory of Entrepreneurship, In Alejandro(Hg.) Portes, The Economic Sociology of Immigration. Essays on networks, Ethnicity, and Entrepreneurship, New York, Russel Sage Foundation S., pp. 166-212.

LIGHT Ivan and KARAGEORGIS Stavros (1994) The Ethnic Economy, In Smelser, Neil, Swedberg, Richard (eds), The Handbook of Economic Sociology, Princeton University Press, Princeton, New Jersey.

MASSEY Douglas and ARANGO Joaquin, GRAEME Hugo, KOUAOUCI Ali, PELLEGRINO Adela, TAYLOR J. Edward (1993) Theories of International Migration: A Review and Appraisal, In Population and Development Review 19 (3).

MIN PYONG Gap, JARET Charles (1985) Ethnic Business Success: The case of Korean Small Business in Atlanta. In Sociology and Social Research 69, pp. 412-35.

MOALLEM Minoo (1991) Ethnic Entrepreneruship and Gender Relations among Iranians in Montreal, Quebec, Canada, Chapt. 11 in Iranian Refugees and Exiles since Khomeini, edited by Asghar Farthi, Contra Costa, CA: Mazda.

MOROKVASIC Mirjana (1988) Minority and Immigrant Women in Self-employment and Business in France, Great Britain, Italy, Portugal and Federal Republic of Germany. Paris/Brussels, Report to the EEC. V/1871/88.

MOROKVASIC Mirjana (1991) Roads to Independence. Self-Employed Immigrants and Minority Women in Five European.

NEWBY Rick, WATSON John andWoodliff David (1999) Measuring Quality of Working Life for the Self-employed: Development of an Instrument. Working Paper, Crawley, Australia.

NOLL Heinz-Herbert (2000) Konzepte der Wohlfahrtsentwicklung: Lebensqualität und "neue" Wohlfahrtskonzepte. WZB-Discussion-Paper.

NUSSBAUM Martha and SEN Amartya (eds.) (1993): The quality of Life. Toronto McGraw Hill. 
OECD (2001) The OECD PROGRAMME FOR INTERNATIONAL STUDENT ASSESSMENT (PISA) http:// www.pisa.oecd.org/

PHIZACKLEA Annie (1988) Entrepreneurship, Ethnicity and Gender, In Westwood, Sally/Bhachu, Parminder (eds.) Enterprising Women. Ethnicity, Economy, and Gender Relations, London and New York, Routledge.

PHIZACKLEA Annie (1990) Unpacking the Fashion Industry. London.

PORTES Alejandro (1995) Economic Sociology and the Sociology of Immigration: A Conceptual Overview. In: Portes Alejandro(Hg.) The Economic Sociology of Immigration. Essays on Networks, Ethnicity, and Entrepreneurship, New York, Russel Sage Foundation, pp. 1-41.

PORTES Alejandro and SENSENBRENNER (1993) Embeddedness and Immigration: Notes on the Social Determinants of Economic Action In American Journal of Sociology.

POWELL Walter W. and SMITH-DOERR Laurel (1994) Networks and Economic Life, In Neil J. Smelser and Richard Swedberg, (ed.) The Handbook of Economic Sociology. Princeton University Press, Chichester, West Sussex.

RATH Jan (2000) Immigrant Business: The Economic, Political and Social Environment (Migration, Minorities and Citizenship). London.

REITZ J. (1980) The Survival of Ethnic Groups. Toronto, Mc Graw Hill.

ROSSI Alice, ROSSI Peter (1990) Of Human Bonding: Parent-Child Relations Accross the Life Course. New York: Aldine De Gruyter.

RUBIN Lilian (1994) Families on the Faultline, New York, Harper Collins.

SASSEN Saskia (1996) "New employment regimes in cities: the impact on immigrant workers" New Community 22(4), pp. 579-594.

SEN Amartya (1993) Capability and Well-Being, In Martha Nussbaum, Amartya Sen (eds.) The quality of Life. (1993), pp. 30-53.

SONG Miri (1999) Helping Out. Children's Labor in Ethnic Businesses, Philadelphia, Temple University Press.

UL HAQ M. (1995) Reflections on Human Development, New York/Oxford.

VEENHOVEN Ruut (2001) Why Social Policy Need Subjective Indicators, WZB Disuccion Paper FSIII 01-404.

VIANELLO Mino (1996) Genere, stile manageriale e clima organizzativo - chi è miglior manager: le donne o gli uomini? Quaderno no.2. Roma: Universitá degli Studi di Roma "La Sapienza".

WALDINGER Roger David (1990) Ethnic Entrepreneurs: Immigrant Business in Industrial Societies. London.

WESTWOOD Sally and BHACHU Parminder (eds.) (1988) Enterprising Women. Ethnicity, Economy, and Gender Relations, London and New York, Routledge.

\section{NOTES}

1. The paper refers to the ongoing RTD research project "The Chances of the Second Generation in Families of Ethnic Entrepreneurs: Intergenerational and Gender Aspects of Quality of Life Processes (Acronym: EthnoGeneration)" financed by the EC. As scientific coordinator of this 
project, I developed the research proposal together with Maria Kontos, Lena Inowlocki and Regina Kreide, all members of the research group at the Institute of Social Research, J.W. GoetheUniversity Frankfurt/Main. The cooperating European project partners are: Floya Anthias and Akosua Boahene, Oxford Brookes University and Ron Ayres, University of Greenwich (UK); Feiwel Kupferberg, Gestur Gudmundsson, Lise Lund, The Danish University of Education, Copenhagen; Maria Liapi, Katy Kylakou, Vassiliki Sioufa, Centre for Research on Women's Issues, Athens; Mirjana Morokvasic and Cristina Catarino, Université Paris X (Nanterre). The study will explore quality of life processes in different European countries in relation to welfare and educational policies (cf. Kreide 2003) that assist families in their socialisation tasks. The analysis will focus primarily on northern European countries (UK, France, Denmark, Germany) since ethnic family businesses of more than one generation exist mostly in countries with a longer history of immigration and ethnic economy. For a more comprehensive view of the phenomenon, we shall also investigate a southern European country (Greece) in which ethnic businesses comprising more than one generation are a new, but growing, phenomenon. We will analyse the different policies that have an impact on the quality of life of ethnic entrepreneurs, male as well as female, focusing especially on welfare and child care policies. With Denmark, we chose a country with highly regulated self-employment and welfare policies, with France, a country with fewer selfemployment support -policies but a widespread day care and day school system. In the UK, ethnic economies have emerged in the framework of immigration from the Commonwealth and have increased through a targeted promotion of self-employment, joined by a day school system. In Germany ethnic business is rather young and has developed out of new work migration flows. There are insufficient public institutions that provide day care for children. In Greece, migrant entrepreneurship has been very high, mainly in the informal sector and recently has also reached the formal sector. Neither self-employment policies nor welfare policies concerning childcare are well developed. The sample will be drawn from ethnic businesses in the food sector since this branch is highly occupied by ethnic entrepreneurs. In each country interviews in 35 ethnic entrepreneur families will be conducted with the parents' generation and with the members of the children's generation who are 16 to 26 years old and living at home. Together with their analyses, the interviews will be part of a common database. On the basis of the theoretical elaboration of the comparative analyses, recommendations for EU policies will be formulated.

2. Ethnic business is defined as migrant family business. On the basis of their niche economies, these family groups are considered to be able to develop economic resources out of ethnic networks, ethnis skills and ethnic financing models (Gold and Light, 2000).

3. Quality of life will be understood as the synthesis of a biographical evaluation of the life course and thus will try to integrate subjective and objective definitions.

INDEX

Geographical index: Allemagne

Mots-clés: économie ethnique, entreprise, famille, générations issues de l'immigration, Turcs 


\section{AUTHOR}

\section{URSULA APITZSCH}

Professeure de sociologie, Johann Wolfgang Goethe Universität, Frankfurt am Main. 